\title{
The new stage of the state's concept evolution: example of Russia
}

Alexander Rakviashvili

Faculty of Economics, Lomonosov Moscow State University

Email: arakviashvili@econ.msu.ru

GSP-1, Leninskie Gory, Lomonosov MSU, The 3d Humanitarian Building, 119991, Moscow, Russian Federation

\begin{abstract}
The article is dedicated to the state's concept evolution. Here is the author's vision of the state as an abstract notion that describes specific governmental relations, formatted in a result of a long evolution process. The special attention is attracted to the Russian political system and features of the new stage of the state's evolution.
\end{abstract}

Key words: State, autocracy, democracy, morality.

\section{JEL: A100, P510, P00}

\section{Introduction}

There are many types of organized coercion created by humans but only the state has become the most demanded and approved by both scientists and ordinary people. However the edge between the banditry (as another type of organized coercion) and the state is too thin and many gangsters are more intelligent, long-sighted and humane than the majority of the political leaders. Nevertheless only the state has a specific characteristic, which is not available to murderers. This characteristic is legitimacy i.e. the willingness of people to obey laws and to endure coercion. This willingness isn't based only on physical force of the authorities, as it is assumed in the McGuire and Olson's Stationary bandit model [14]. In contrast with another popular explanation, it also doesn't have a straight connection 
with the rules and formal procedures $[15$, p. $21 ; 12$, p. 78]. Of course, legislation is very important, because it helps civilians to recognize the rules of political struggle and thereby make the process of evaluation of personal preferences and personal willingness to obey these rules easier. But legislation is the instrument with limited impacts as it's evident from the bad end of the majority of totalitarian leaders each of which usually ruled the country in accordance with the laws.

At the same time, if we are looking for what kind of methods guaranteed the legitimacy in the past and what is the source of it today we can define the evolution path of domination relationship and also define possible ways of its further development. And in this process developing countries with unstable and forming political systems are natural polygons for the experiments and how it will be shown below there is already a country - Russia - where it is possible to define the elements of the authority relationship, which may indicate possible features of the future model of the state.

\section{Evolution of the State}

As Foucault said, "the government of men by men -whether they form small or large groups, whether it is power exerted by men over women, or by adults over children, or by one class over another, or by a bureaucracy over a population - involves a certain type of rationality" [11, p. 254]. This rationality, or in this case criteria of decision making, ensuring the legitimacy, historically were close with the myth of divine origin of leaders.

Sacralization caused voluntary submission, as well as it caused the appearance of external restrictions of the authority, which is good illustrated by views of people about the principles of justice and pleasing to God affairs. Exactly that's why protégé of God couldn't break God's laws on their own.

Even if these restrictions were frequently broken, they constantly played important protective role, indicating what was allowed to do, and 
what wasn't. These kinds of views were so important and natural that they manifested themselves in culture and philosophy at all times.

The idea of limited state is mirrored in tragedies of Sophocles "Antigone" and "Oedipus Rex", "The Divine Comedy" of Dante Alighieri, "The Allegory of Good and Bad Government" of Ambrogio Lorenzetti and in works of major part of philosophers of the Antiquity and the Middle Ages [17]. As the source of the authority is not people, but rules of justice prevailing upon the preferences of the lieges a typical leader in the past had to obey these abstract rules, but no the people wiliness. ${ }^{1}$

Besides the legitimacy, sacralization of the leaders stimulated authorities' personification, because it is much easier to iconize one person, but not a group of them. Personificated authority is well illustrated in the words of Henrih VIII to the Parliament (1545), where he marked himself as a "supreme head" of the parliamentary [13].

The acquisition of sovereignty by European kings after The Thirty Years' War (1618-1648) stimulated the expansion of this authority, what was naturally accompanied by the expansion of the civil servants. Step-by- step Bureaucracy was becoming mass and shortly after wrested the power from the kings [9, p. 126-188]. A good example of these changes is a famous phrase of Louis the XIV «I am the State». It is so well known not because of reflecting the true state of affairs, but because it clearly contradicted the facts, namely the great for those times bureaucratic machine [4, p. 175].

But transition from personalized authority to impersonal authority of the sovereigns wasn't only a symbolic change. Coincided with the development of science, reformation, Age of Discovery and

\footnotetext{
${ }^{1}$ Erasmus said: «It is no true state of happiness in which the people are given over to idleness and wasteful extravagance, any more than it is true liberty for everyone to be allowed to do as he pleases. Neither is it a state of servitude to live according to the letter of just laws. Nor is that a peaceful state in which the populace bows to every whim of the prince; but rather [is it peaceful] when it obeys good laws and a prince who has a keen regard for the authority of the laws.» [10, p. 212].
} 
acceleration of economic growth, these changes stimulated destroying of the sacral base of the authority and thus the main source of the legitimacy.

It is well illustrated by The French Revolution, where the authority, which had deprived sacral aureole and hadn't created another source of legitimacy, ${ }^{2}$ grew quickly to the tyranny and collapsed quickly as well.

As the authority was gradually losing the aureole of sacral, the need in new source of legitimacy soon became evident. It took 2,5 centuries after The Peace of Westphalia, before it was found. And it was sovereignty of people, provided unprecedented stability of the power in the second half of the XX century.

Even at the end of the XIX century politics elected by people weren't totally free from the restrictions, imposed by laws of God, following which was the main aim of the leaders. Thus, the President Stephen Grover Cleveland in 1887 vetoed the bill which obligated the federal government of the USA to spend 10000 US dollars in order to help farmers, affected by drought. Despite the fact that it was a really trivial sum, Cleveland said, that «though the people support the Government the Government should not support the people» [8].

But in the next century the changes in basic attitudes of people who perceived the state as a tool for performance of their own desires and not the rules of justice, finally destroyed external restrictions of the authority and contemporaneously totally changed the idea of the state to any decision, accepted by the majority [7, p. 331]. Similarly, when the opinion of the majority becomes the criteria of the trueness, all footprints of laws of God, requirements of nature, rules of justice and any other sources of the external restrictions of the authority disappeared. The opinion of a median voter becomes the main determinant of the goals of politicians. And the idea that an opinion is

\footnotetext{
${ }^{2}$ See some attempts of creating alternative religion [3].
} 
only an opinion and nothing else was ignored, and «people wishes» became a universal justification for any action.

It is important to emphasize that both democratic government and authoritarian regime are based on support of the majority of civilians (at least on support of the active civilians majority) anyway. The difference between them is only in methods of how this support is achieved. In authoritarian countries it is commonly censorship to manipulate public opinion, corruption as a method of financing stakeholders, militarization as a source of fear, numerous privileges of separate groups, which are important for maintenance of loyalty of the citizens. In contrast democratic countries more frequently use lobbyism, high activity of the government in redistributing of income in order to support main electoral groups, which are important for ruling parties, and also permanent coalitions of different political forces.

That's why it's no matter what kind of political system is meant. Modern government bases not on the moral norms or abstract concepts of the proper state of the world, but on the ideas and methods, maintaining support of the majority.

Of course, it is difficult to dispose of any external restrictions of the authority. For example the order of Herod the Great to kill children is impossible in principle for any contemporary leaders, i.e. laws at least in the weak form, but still reflect the rules of justice, accepted in society. But in the majority of cases politics are led only by internal restrictions, generated by the representatives of interest groups and goals of the main electoral groups.

In result in modern society the expression «state» ceases to describe the state of the authority of separate leaders, but is an abstract description of the specific (impersonal) relationship of authority and subordination, based on physical force and legitimacy, the source of which (opinion of the majority), establish very weak external restrictions. 


\section{Continuing of evolution of the State}

Destruction of the external restrictions of the authority will sooner or later come to a logical end, but destruction of residual morality will certainly precede it. Morality as judgments about the proper independent of the views and concerns of individuals by definition contains an element of faith, that's why simultaneously with secularization of the societies morality restrictions has become weaker. For example gay marriage settle down worse in more religious south of Europe than in the north.

But for the final destruction of the external restrictions of the authority there is no need to wait when people aren't be led by morality and their faith in God will be perceived as an anachronistic and amusing consequence of the evolution. It will be quite enough if the moral restrictions become so weak, that the majority of civilians will ignore them if there is adequately material consideration. And implementation of only four conditions is necessary for the achievement of this condition.

Firstly, it needs the society with inhomogeneous morality, what can be due to the neighborship of many nations, social groups and religions within one political field. In this environment it is easier to prevent the appearance of powerful groups of interest, using political system in order to implement their own ideas of the proper.

Secondly, the size of government, of bureaucratic system, stateowned companies and dependent companies should become so big that free people, entrepreneurs and their employees were in absolute minority. Since huge developed technologies make it possible to ensure the existence of majority based only on working minority, eventually, societies could consist of a small number of producing citizens and parasitizing majority with active distributing bureaucracy. In this environment a real risk of tyranny of majority will emerge in its most sophisticated form, when nonproducing majority exploits producing minority, though political activity of a little percent of people like 
entrepreneurs can't remove the restrictions and taxes generously introduced by the majority.

Thirdly, in the country there should be formed well-knit ruling elite, gaining main income by exploiting citizens and creating distribution channels for maintaining people's loyalty.

Finally, asymmetric hierarchy of the rights should be built among the main groups of citizens: entrepreneurs, non-producing majority and leading elite. This hierarchy should consist of three main levels.

1. Leading elite is untouchable. If their actions aren't supported by majority, their recourses are distributed in order to purchase the loyalty of main groups of interests. Fragmentation and small size of these groups will create competition for being purchased, namely it will lead to something like monopsony and as a result there will be lower prices on the "market of loyalty" than they are in modern state.

2. Entrepreneurs are a well-protected group, which gets all benefits from the rule of law while they are paying taxes and avoids attempts to influence political system. At the same time many regulations, for example, implemented through trade unions, create the illusion of entrepreneur's subordination to people. Considering the active propaganda belittles valuation of the entrepreneurship, the producing part of citizens will have too little chance to enlist the support of the majority, necessary to displace the ruling elite.

3 . In the result the asymmetry of rights makes those on whom the legitimacy of the leading elite is based, slaves in royal robes. None of the members of the majority will have any right behind the ruling elite and any attempt of disagreement from several groups will replace them out of the active majority, which is the main recipient of transfers from the government. Since the majority doesn't produce anything valuable, these transfers are the only source of their existence and that, in many ways, the animal instinct will constantly prevail over all other incentives, including those determine by morality. 
Entrepreneurs being formally a persecuted class in fact will be able to count on greater protection of their rights, mainly of the property rights, but they will have to swap this protection for the main part of their wealth and all their political rights.

At the same time the regime will get resources and in fact unlimited power over the society.

And even if there is low probability that this kind of political system will appear in any country in the near future, there is at least one country where almost all the conditions of stable transition to the "tyranny of the majority" are already implemented.

As it was noted above, it is hard to find a leader, who is able to reproduce the order of Herod the Great, but in fact it isn't fully true. On 28 December 2013, after more than 2000 years after this order, on the initiative of the ruling elite and the president a so-called law of "Dima Yakovlev" was initiated in Russia [6]. Formally, this law prohibits adoption of Russian orphans, but essentially it dooms thousands of children to death or life in appalling conditions [1], what is much more immoral than the dozens of children - the victims of Herod (if this decree occurred at all). But at the same time public opinion polls show, that $56 \%$ of Russians support this law and only $21 \%$ are oppose it [5].

What is going on in Russia, if the leader doesn't have any responsibilities behind the citizens, based on morality. Why is the leader able to implement such-terrific rules without physical pressure? $?^{3}$

As a matter of fact the law of "Dima Yakovlev" accepted on The Massacre of the Innocents, points only to the possibility of the leading elite to substitute morality using material compensations: transfer payments, privileges, positions in the hierarchy, protection, i.e. this fact

\footnotetext{
${ }^{3}$ There are many other same examples of the violence, initiated or stimulated by russain authoreties, and ignored by majority of the people: The law of "Dima Yakovlev" could be added S.Magnitsky'a death in the prison, killing of journalists, arrested politics and opposition activists, arrested activists of Greenpeace and so on.
} 
illustrates the proximity of the point where the outer limits of the authority will be destroyed.

Firstly, Russia is a big multinational, multicultural and multireligious country and although formally the majority of the citizens are Orthodox Christians, decades of soviet domination and promotion of atheism actually destroyed religiousness traditional for Russian society. That's why Christian core in Russia isn't much bigger then, for example, Muslim or Jewish, despite the fact that a significant part of people doesn't include itself into a particular religion, but displays only the residual elements of faith.

Secondly, authoritarian political system in Russia was formed at the expense of a fairly stable and closed leading elite (based on intelligence agencies), taken strong/firm possession of all the major sources of the country.

Thirdly, today it can be argued that free and producing part of the society is in minority. Only several facts to prove it:

- Government dominates in the economy using vast bureaucratic machine, which has made corruption a norm [18].

- With population of $143 \mathrm{mln}$ people, $67,5 \mathrm{mln}$ are employed and $20,5 \mathrm{mln}$ of them work in government sectors [16].

- Social payments rose for 10 years between 2000 and 2010 by more than 5 times (in real terms).

- In manufacturing, the share of private sector is only 53,4\% [16], and in general the most unpretentious estimation the government controls about $50 \%$ of the economy [2].

Finally, private enterprise has been already marginalized and has been totally controlled by corrupted bureaucracy, while public services and work in public companies is a top priority for «successful» people. But at this stage of development free people in Russia don't get decisive political influence mainly only under the pressure of government power, but not as a consequence of propaganda or specific incentives of the majority described earlier. It is impossible in Russia to talk about 
entrepreneur's security or poverty protection. In fact power pressure only undermines the possibilities of productive activities and thus does not allow finally build a stable dictatorship of the majority.

Nevertheless, the very appearance of the possibility of transforming the authority in Russia into a new form, which has had no precedent, is extremely important and requires attention. And even if a decisive step needed to create a new form of power relationship isn't made (for whatever reason), it is possible to argue that Russia lifts the veil of secrecy over the future of the state following naturally out of the conditions that have developed in the world today.

\section{Conclusion}

Summing up, it should be noted, that "the opinion of the majority", which is the main source of the legitimacy today, significantly weakened the outer limits of the authority. Constant degradation of morality, defining the limits of freedom of politicians, as well as a possibility of the stable existence of parasitic majority ${ }^{4}$ give the governing elites the way of managing, which is very difficult to give up. But, of course, there is a positive fact, that there is no place where the transformation to a totally free from external restrictions state today has been already finished. And the main reason of this is the unconventional, unusual rules of the game, it requires. Actually ruling elite after defining producing minority should isolate and marginalize it and also create as comfortable environment for it as it is possible in order to stimulate entrepreneurs to work hard, pay taxes and ignore political activities. If propaganda, appealing to base instincts and momentary whims of people are normal for politics, the hidden, principled and consistent protection of entrepreneurs is a nontrivial idea for the authorities, especially in authoritarian countries, like Russia. And that's why in particular the evolution of the state described above

\footnotetext{
${ }^{4}$ Due to the unprecedented development of techniques and technologies
} 
most likely will be not as rapid as it might seem, but such type of transitions is more than logical and plausible, taking into consideration the observed today and in the past trends.

\section{References}

1. Алленова О. Нам не на кого надеяться, кроме самих себя // http://www.kommersant.ru/doc/2202990

2. Доля государства в экономике РФ должна снизиться до 30\% Кудрин // http://ria.ru/crisis/20091005/187644688.html

3. Олар А. Культ Разума и культ Верховного Существа во время французской революции. - М.: Сеятель, 1925

4. Понятие государства в четырех языках - СПб.; М.: Европейский университет в Санкт-Петербурге: Летний сад, 2002

5. Усыновление российских детей иностранцами http://fom.ru/Bezopasnost-i-pravo/10749

6. Федеральный закон от 28 декабря 2012 года № 272-Ф3 «О мерах воздействия на лиц, причастных к нарушениям основополагающих прав и свобод человека, прав и свобод граждан Российской Федерации» Federal act from 28.12.2012

7. Хайек Ф. Право, законодательство и свобода: Современное понимание либеральных принципов справедливости и политики М.: ИРИСЭН, 2006

8. Congressional record

(1887)

https://archive.org/details/congressionalrec50aunit

9. Creveld M. The Rise and Decline of the State // Cambridge university press, 1999

10. Desiderius Erasmus The Education of a Christian Prince (1516) // Columbia University Records of Civilization, New York: Octagon Books, 1963

11. Foucault M. Omnes et Singulatim: Towards a Criticism of 'Political Reason'. The Tanner Lectures on Homan Values // Delivered at Stanford University October 10 and 16, 1979 
12. From Max Weber: Essays in Sociology. - NY, Oxford University Press, 1946

13. King Henry VIII's Speech in Parliament, towards the latter end of his Reign. [24 December 1545] // http://www.luminarium.org/renlit/tudorspeech.htm

14. McGuire M.C., Olson M. The Economics of Autocracy and Majority Rule: The Invisible Hand and the Use of Force // Journal of Economic Literature. March, Vol. 34, 1996. - pp. 38-73

15. North D. Structure and Change in Economic History - NY: W.W. Norton, 1981

16. Russian Federation Federal State Statistics Service // http://www.gks.ru

17. Skinner Q. Ambrogio Lorenzetti's Buon Governo Frescoes: Two Old Questions, Two New Answers // Journal of the Warburg and Courtauld Institutes, Vol. 62, 1999. - pp. 1-28

18. Transparency International The Corruption Perceptions Index // http://cpi.transparency.org

19. 